\title{
Co-existence of a rare dyspnea with pericardial diaphragmatic rupture and pericardial rupture: a case report
}

\author{
Necdet Öz ${ }^{1}$, Ahmet Bülent Kargı², Arife Zeybek ${ }^{3}$ \\ 1Private Medstar Antalya Hospital, Department of Thoracic Surgery, Antalya, Turkey \\ ${ }^{2}$ Private Medikalpark Hospital, Department of Thoracic Surgery, Antalya, Turkey \\ ${ }^{3}$ Medicine School of Muğla Sıtkı Koçman University, Department of Thoracic Surgery, Muğla, Turkey
}

Kardiochirurgia i Torakochirurgia Polska 2015; 12 (2): 173-175

\begin{abstract}
Pericardial-diaphragmatic rupture is a rare condition which occurs after blunt trauma and involves the herniation of abdominal organs into the pericardium. A 77-year-old female patient presenting with complaints of palpitation and difficulty in breathing was admitted to the emergency room. Left lateral thoracotomy revealed the herniation of abdominal organs into the thorax. A pericardial-diaphragmatic rupture and a pericardial rupture were found to co-exist. The diaphragm and the pericardium were repaired primarily. The case is presented here because herniation of abdominal organs into the pleural cavity through the pericardium is a rare condition.

Key words: obtuse trauma, diaphragmatic rupture, pericardial rupture, pericardial diaphragmatic rupture.
\end{abstract}

\section{Introduction}

Diaphragmatic rupture (DR) is seen in $2.5 \%$ of thoracoabdominal traumas. It can grow one-sided, two-sided or into the pericardium [1]. One-sided left DR is the most common form, and pericardial diaphragmatic rupture (PDR) is the rarest form [1]. Diagnosis is often difficult. Delay in diagnosis and accompanying pathologies increase mortality and morbidity [2, 3]. The ideal approach for treatment is primarily operational repair of the abdomen $[2,4,5]$.

\section{Case study}

A 77-year-old female presented in the emergency room with complaints of palpitation, difficulty in breathing and digestion problems. Forty days previously she had a nonvehicle traffic accident. She was treated by a general surgery expert in a different center for general body trauma, and a broken right hip and left tibia. Stomach pain, digestion problems, palpitation and breathing difficulties that

\section{Streszczenie}

Przepuklina przeponowo-osierdziowa to rzadkie schorzenie występujące po tępych urazach, w którym dochodzi do przedostania się organów brzusznych do osierdzia. W pracy opisano przypadek 77-letniej pacjentki zgłaszającej palpitacje i trudności w oddychaniu, przyjętej na oddział ratunkowy. Lewa boczna torakotomia uwidoczniła przedostanie się narządów brzusznych do klatki piersiowej. Stwierdzono współwystępowanie przepukliny przeponowo-osierdziowej oraz przepukliny osierdziowej. Przeponę oraz osierdzie zaopatrzono pierwotnie. Przypadek ten zaprezentowano, ponieważ wpuklanie się narządów brzusznych do jamy opłucnej przez osierdzie jest rzadkim schorzeniem.

Słowa kluczowe: tępy uraz, przepuklina przeponowa, przepuklina osierdziowa.

had persisted for the last 10 days increased during the last three days. The patient was sent to us with a pre-diagnosis of late DR by the general surgery expert who treated her, in order to get our opinion of thoracic surgery. The patient had a medical history of hypertension.

Her physical examination showed pulse of 110 beats/ min, blood pressure 130/80 mmHg, oxygen saturation 93\% without oxygen, and she had dyspnea and orthopnea. Respiratory sound had decreased in the left baseline. There was frequent palpation and tenderness in the abdomen. Routine laboratory tests showed $10.6 \mathrm{~g} / \mathrm{dl}$ hemoglobin and the biochemical results were within normal limits. The left diaphragm was not visible in the posteroanterior chest radiograph (Fig. 1). The left field view showed heterogeneous parenchyma opacity. In the chest computed tomography, the abdominal organs were observed to have moved into the left hemithorax. The case was considered to be a late $\mathrm{DR}$, and a left thoracotomy in general anesthesia was per-

Address for correspondence: Necdet Öz, Private Medstar Antalya Hospital, Department of Thoracic Surgery, Yıldız Mah. Çakırlar Cad. No: 19 Muratpaşa, Antalya, Turkey, phone: +905325638073, fax: +902423109290, e-mail: drnecdetoz@gmail.com 


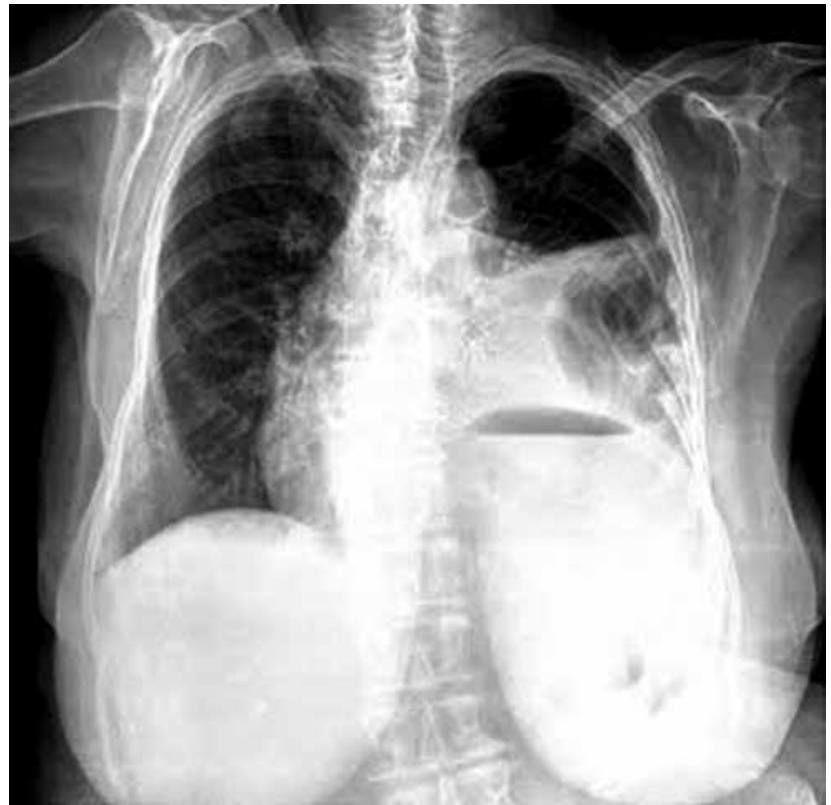

Fig. 1. PA chest X-ray. The left diaphragm cannot be seen. There are heterogeneous opaque areas with a lost view of parenchyma on the left

formed on an emergency basis. In the exploration, it was observed that the abdominal organs had moved into the thorax, the tissue on the left lung had collapsed, a pericardial rupture (PR) of $7 \mathrm{~cm}$ had occurred in front and parallel to the left phrenic nerve, and there was a rupture of $6 \mathrm{~cm}$ into the pericardium in the transverse position to the diaphragm's position next to the pericardium (Fig. 2). The organs were moved inside the abdomen, and firstly the PDR area, and then the PR area that extended along the phrenic nerve in the pericardium were primarily repaired. During repair, serious arrhythmia was observed due to the retraction of the heart. The patient was discharged without complications and was followed up for two years without any symptoms.

\section{Discussion}

Diaphragmatic rupture is the loss of diaphragmatic integrity which occurs because of the sudden increase of pressure in the abdomen after an obtuse thoracoabdominal trauma. Diaphragmatic rupture is observed in $0.82 .5 \%$ of obtuse thoracoabdominal traumas [2]. Pericardial diaphragmatic rupture accounts for $0.9 \%$ of all traumatic DRs $[2,5,6]$. Movement of the abdominal organs into the pericardium can cause life-threatening problems in the digestive system. What might rarely occur is PR or PR rupture taking in also the diaphragm, which might have herniation into the pericardium and pleura together [5, 7]. In our case, we observed DR into the pericardium, also accompanied by $P R$ in front of the left phrenic nerve.

According to the DR's location, the abdominal organs are displaced into the thorax. The symptoms vary depending on the location of the rupture and the organ that is ruptured. In the early stages, patients may experience an

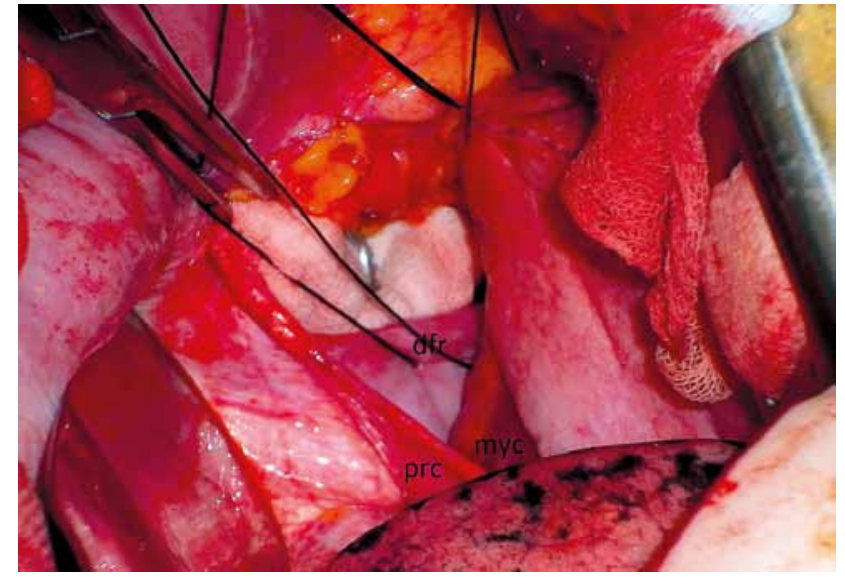

Fig. 2. The pericardio-diaphragmatic rupture area in the exploration (dyf - diaphragm, myc - myocardium, prc - pericardium)

acute abdominal scenario. Digestive problems, abdominal pain and bowel obstruction symptoms may occur in the later stage. Again, the abdominal organs that are displaced into the thorax might press on the lungs, causing significant respiratory distress. In the rare PDR, there might be heart problems ranging from palpitation to cardiogenic shock $[3,5]$. Sometimes PR may be accompanied by herniation of the heart [8]. Although a very rare occurrence, it has been reported in the IBIS standard that a rupture into the pericardium may also happen into the pleural space [5, 7]. In that case, the circulatory, respiratory and digestive symptoms and findings might be observed separately or all together. Our case led finally to DR into the pericardium and an accompanying separate PR space in front of the left phrenic nerve, the herniation of the abdominal organs into the left pleural space and the observation of the symptoms and findings that belong to each of those three systems. Given the above, the case is rarer than PDR.

In patients with multiple traumas accompanied by intra-abdominal organ injury, the diagnosis may be easier but difficult to recognize. In patients with trauma, in whom laparotomy and thoracotomy have been applied, the rate of occurrence of DR is $4-6 \%$ [2]. In $15 \%$ of the cases, there is late diagnosis [2]. In the cases with late diagnosis, mortality and morbidity are higher. Ganie et al. reported 3 cases and $27 \%$ mortality among 11 late cases [3]. In our case, the diagnosis was delayed because of multiple traumas, nonaccompaniment of abdominal pathology and no symptoms in the early stages. However, the case was quickly returned to normal by appropriate diagnosis and treatment.

In spite of the advanced diagnostic methods used in radiology, the most important diagnostic method is posteroanterior chest radiography [3, 9]. Ultrasonography, chest computed tomography, magnetic resonance imaging, barium passage, upper gastrointestinal endoscopy and peritoneal lavage are other methods that help with the diagnosis [9]. In our case, DR was suspected after posteroanterior chest radiography, which was confirmed with chest computed tomography. Pre-operative examinations of the patient arose suspicion of a left DR, but intraoperatively 
the PDR was found. Echocardiography before the operation could have helped with the diagnosis of PDR.

Because the focus of the treatment is primarily surgical repair, which may be accompanied by abdominal injury in the early stages, it is more appropriate to approach the abdomen $[3,9]$. In the cases that are over ten days, thoracotomy should be preferred due to the adhesions in the thorax $[2,9,10]$. In our case, thoracotomy was preferred because the diagnosis was late. However, adhesion was not observed even 40 days after the trauma. In this case, because it was first considered left DR, left thoracotomy was applied. However, due to the necessity of moving the heart upwards during repair, it led to serious arrhythmia. If PDR had been diagnosed earlier and isolated, a western approach from the abdomen might have been easier.

McCutcheon et al. reported the successful laparoscopic treatment of intrapericardial diaphragmatic hernia [11]. However, in our case, repair of the PR space that was found in front of the left phrenic nerve was not possible in the abdomen; therefore, thoracotomy was a more appropriate approach. If the PR had not been fixed, it might have caused herniation of the heart.

\section{Conclusions}

Pericardial diaphragmatic rupture and the accompanying herniation of the transpericardial abdominal organs into the pleural space is a rare pathology, which occurs after obtuse traumas. It might cause symptoms of abdominal organs, cardiac problems and problems in the respiratory system. The appropriate treatment in the early stages should be primary repair of the abdomen. However, as seen in our case, if there is herniation into the thorax accompanied by PR, left thoracotomy should be preferred.
The case was presented as a poster at the $6^{\text {th }}$ National Thoracic Surgery Congress in Antalya during 28 April 1 May 2011.

\section{Disclosure}

Authors report no conflict of interest.

\section{References}

1. Tornout FV, Leuven MV, Parry W. Pericardio-diaphragmatic avulsion and concomitant rupture of the central tendon of the diaphragm. Eur J Cardiothorac Surg 2004; 26: 655-657.

2. Shah R, Sabanathan S, Mearns AJ, Choudhury AK. Traumatic rupture of diaphragm. Ann Thorac Surg 1995; 60: 1444-1449.

3. Ganie FA, Lone H, Lone GN, Wani ML, Ganie SA, Wani N, Gani M. Delayed presentation of traumatic diaphragmatic hernia: a diagnosis of suspicion with increased morbidity and mortality. Trauma Mon 2013; 18: 12-16.

4. Meng RL, Straus A, Milloy F, Kittle CF, Langston H. Intrapericardial diaphragmatic hernia in adults. Ann Surg 1979; 189: 359-366.

5. Barrett J, Satz W. Traumatic, pericadio-diaphragmatic rupture: an extremely rare cause of pericarditis. J Emerg Med 2006; 30: 141-145.

6. Heiner JD, Harper HM, McArthur TJ. Intrapericardial diafragmatic hernia. Western J Emerg Surg 2010; 11: 532-533.

7. Arslan E, Işık AF, Sanlı M, Uluşan A, Elbeyli L. A rare complication of blunt trauma; diaphragm-pericardium rupture and cardiac herniation in a child case. Ulus Travma Acil Cerrahi Derg 2013; 19: 363-365.

8. Witkowski Z, Lasek J, Wujtewicz M, Stasiak M, Marks W, Kawecka A. Pericardiodiaphragmatic rupture and cardiac herniation after multiple blunt trauma: diagnostic and therapeutic difficulties. J Thorac Cardiovasc Surg 2005; 130: e1-2.

9. Ülkü R, Özçelik C, Eren Ş, Balcı A, Eren N. Travmatik Diafragma Rüptürleri. Turk Gogus Kalp Dama 1999; 7: 454-456.

10. Sharma OP. Pericardio-diafragmatic rupture: five new cases and literature review. J Emerg Med 1999; 17: 963-968.

11. McCutcheon BL, Chin UY, Hogan GJ, Todd JC, Johnson RB, Grimm CP. Laparascopic repair of traumatic intrapericardial diafragmatic hernia. Hernia 2010; 14: 647-649. 